\title{
Peran Dukungan Sosial Teman Sebaya Terhadap Ketahanan Psikologis Remaja Yang Mengalami Konflik
}

\section{The Role Of Social Support Of My People To The Psychological Resilience Of Adolescents In Conflict}

\author{
Wildan Akasyah ${ }^{1}$, Hendy Muagiri Margono ${ }^{2}$, Ferry Effendi ${ }^{3}$ \\ ${ }^{1}$ Institut IImu Kesehatan Bhakti Wiyata Kediri, \\ ${ }^{2}$ Psichyatrist at RSUD DR. Soetomo Surabaya, \\ ${ }^{3}$ Faculty of Nursing Universitas Airlangga \\ e-mail: wildan.akasyah@iik.ac.id
}

\begin{abstract}
ABSTRAK
Konflik merupakan masalah yang sering kali terjadi pada remaja. Hal ini dapat memberikan dampak psikologis dan gangguan mental emosional pada remaja dan jika berangsur lama dapat menimbulkan efek yang buruk baik dari mental maupun fisik. Ketahanan psikologis tidak secara langsung ada pada diri remaja, melainkan melalui proses pembelajaran dan dukungan. Studi ini menganalisis dukungan sosial teman sebaya dan ketahanan psikologis remaja yang mengalami konflik dan masalah emosional akibat bullying. Pendekatan Cross-sectional digunakan dalam penelitian ini. Sampel yang digunakan berjumlah 94 remaja. Data diambil dengan cara memberikan kuesioner demografi, informed conscent, the Perceived Social Support from Friend (PSS-Fr) Scale dan The Brief Resilience Scale (BRS). Data di proses dengan statistik dekriptif dan dianalisis menggunakan Spearman's rho, menggunkan software SPSS. Hasil dari penelitian Usia rata-rata remaja dalam studi ini adalah 14 tahun. Hasilnya menunjukkan bahwa ada korelasi positif antara dukungan sosial teman sebaya dengan ketahanan psikologis remaja $(p<0.05)$. Kesimpulan Penelitian ini megidentifikasi korelasi antara peran dukukan sosial teman sebaya dengan ketahanan psikologis remaja yang mengalami konflik dan masalah emosional akibat bullying. Hal ini menjaleasakn bahwa dukungan sosial teman sebaya memiliki dampak yang positif terhadap ketahanan psikologis remaja dalam menghadapi konflik.
\end{abstract}

Kata kunci : Dukungan Sosial, Ketahanan Psikologis, remaja konflik

\section{ABSTRACT}

Conflicts are a common problem for teenagers. It can provide psychological impact and emotional, mental disorders in adolescents and, if long-lasting, can negatively affect both mental and physical. Psychological resilience is not directly present in teenagers but through the process of learning and support. This study analyses the social support of peers and adolescents' psychological resilience who experience conflict and emotional problems due to bullying. Methods. Cross-sectional approaches are used in this study. Samples used amounted to 94 teenagers. Data is take by providing demographic questionnaires, consent, the Perceived Social Support from Friend (PSS-Fr) Scale, and The Brief Resilience Scale (BRS). The Data is in process with detailed statistics and analyzed using Spearman's rho, used SPSS software. Results. The average age of teenagers in 
this study was 14 years old. The results showed a positive correlation between peer social support and adolescent psychological resilience $(p<0.05)$. The conclusion of this research is a correlation between social play's role with the psychological stability of teenagers who have experienced conflicts and emotional problems caused by bullying. It is through that peer social support has a positive impact on adolescent psychological resilience in the face of conflict

\section{Keywords: Social support, psychological resilience, youth conflict}

\section{PENDAHULUAN}

Gangguan ketahanan psikologis maupun emosional menjadi masalah yang perlu diperhatikan pada remaja. Ketahanan merupakan adaptasi positif dari trauma maupun stres (Luthar, Cicchetti, \& Becker, 2000). Ketahanan tidak serta merta ada pada perkembangan remaja (Lerner et al., 2013). Mempelajari ketahanan dapat memperoleh pemahaman menyeluruh tentang respons manusia terhadap trauma dan stres sehingga memiliki kemampuan yang baik dalam mengelola stresor (Bonanno, 2004).

Transisi remaja merupakan periode dari anak-anak ke dewasa yang mengalami proses perubahan. Perkembangan fisik dan psikologis yang cepat pada remaja biasanya disertai oleh perubahan kognitif, emosional, dan sosial (Adams, 2015). Konflik internal dan interpersonal dapat terjadi saat masa transisi dari masa kanak-kanak ke remaja karena masa ini digunakan untuk mendapatkan identitas pribadi yang konkret. Selain itu komitmen untuk memainkan peran tertentu sebagai orang dewasa di dalam masyarakat dan keterampilan kompetensi sosial juga dipelajari oleh remaja.

Tindakan bully pada remaja menjadi masalah psiko-sosial yang kompleks (Zhou, Liu, Niu, Sun, \& Fan, 2017) dan seringkali memicu konflik yang serius diantara remaja (Adams, 2015). Bullying dapat diartikan pengalaman yang terjadi ketika seseorang merasa teraniaya oleh tindakan orang lain dan ia takut apabila perilaku buruk tersebut akan terjadi lagi. Korban merasa tidak mampu untuk mencegahnya (Mellor, 1995)

Kejadian bullying di sekolah yang terjadi jauh lebih banyak dari yang terlihat di permukaan, karena kasus yang dilaporkan hanya sebagian kecil sehingga mirip seperti fenomena gunung es. KPAI juga menyebutkan bahwa kasus bullying yang menimpa anak-anak di Indonesia, baik di pedesaan maupun perkotaan hampir sama rata (Saubani \& Sopia, 2017). Bullying ini bisa terjadi di sekolah swasta, negeri, bahkan sekolah bertaraf internasional (Setyawan, 2014).

Penelitian tentang Violence Against Children yang dilakukan oleh PBB pada tahun 2006 melaporkan bahwa 20-65\% anak sekolah mengalami bullying verbal. Verbal bullying merupakan bentuk kekerasan yang paling sering terjadi di sekolah (Pinheiro, 2006). Berdasarkan laporan UNESCO tentang Education Digest tahun 2011, diperkirakan 246 juta anak-anak dan remaja mengalami kekerasan dan bullying sekolah dalam beberapa bentuk setiap tahunnya (UNESCO, 2011).

Pada tahun 2014-2015 sebesar 20,8\% remaja usia 12-18 tahun (lebih dari 5 juta) melaporkan bahwa mereka telah di buli di sekolah (Lessne \& Yanez, 2016). Data lain menunjukkan $17,6 \%$ anak laki-laki dan $15,3 \%$ anak perempuan dilaporkan menjadi korban bullying (Rasalingam, Clench-Aas, \& Raanaas, 2016). Penelitian lain menunjukkan $15-30 \%$ secara umum remaja pernah manjadi korban bullying (Zhou et al., 2017). Dalam penelitian lain menunjukkan bahwa 
kejadian bullying banyak terjadi pada usia remaja awal yaitu 14-15 tahun (Peltzer \& Pengpid, 2017; Rhee, Lee, \& Jung, 2017; Tanrikulu \& Campbell, 2015)

Kasus bullying menduduki peringkat teratas pengaduan masyarakat. Dari 2011 hingga agustus 2014, KPAI mencatat 369 pengaduan terkait masalah tersebut. Jumlah itu sekitar $25 \%$ dari total pengaduan di bidang pendidikan sebanyak 1.480 kasus. Bullying yang disebut KPAI sebagai bentuk kekerasan di sekolah, mengalahkan tawuran pelajar, diskriminasi pendidikan, ataupun aduan pungutan liar (Setyawan, 2014)

Kejadian konflik bullying pada remaja ini juga marak terjadi diberbagai kota di Jawa Timur. Kasus terbaru terjadi di SMPN 4 Nganjuk dengan korban seorang siswi yang dibuli oleh teman sebayanya karena memiliki kekurangan. Bentuk bullying yang diberikan berupa ejekan dan perekaman pada media hdanphone (Nugroho, 2017b). Kejadian bullying juga terjadi di SMPN 1 Tulungangung dengan korban siswa laki laki berusia 14 tahun (Sukarelawati, 2017). Pelaporan kasus bullying juga terjadi di salah satu sekolah dasar (SD) di Mojoroto Kota Kediri. Pelaku tediri dari tiga orang yang merupakan siswa kelas enam. Mereka melakukan pengeroyokan terhadap adik kelasnya, kelas lima, pada 31 Agustus lalu. Kasus itu kemudian dilaporkan oleh orang tua korban pengeroyokan ke Unit Pelayanan Perempuan dan Anak (PPA) (Nugroho, 2017a). Berdasarkan penelitian data menunjukkan kejadian bullying yang terjadi pada remaja usia 12-18 tahun sebanyak 20\%-30\% (Lessne \& Yanez, 2016; Zhou et al., 2017).

Hasil menunjukkan bahwa bullying yang dilakukan berhubungan dengan tingkat penyesuaian psikologis yang rendah dan penyesuaian sosial dan tingkat tekanan psikologis yang tinggi, gejala depresi, dan gejala kesehatan fisik yang merugikan (Undheim, Wallander, \& Sund, 2016). Gangguan mental emosional pada korban bullying dapat berlanjut menjadi gangguan yang lebih serius seperti gangguan jiwa apabila tidak berhasil ditanggulangi (Zauszniewski \& Bekhet, 2012)

Konflik bullying akan membawa dampak negatif yang signifikan terhadap kesehatan fisik dan psikologis remaja, seperti, mual, sakit kepala, masalah tidur, kelelahan, perilaku merugikan diri sendiri, kesepian (Zhou et al., 2017) depresi (Murshid, 2017), psikosis dan ide bunuh diri (Bang dan Park, 2017) daripada mereka yang tidak memiliki riwayat semacam itu. Gejala depresi menjadi efek yang merugikan yang ditemukan pada korban bullying (Zhou et al., 2017).

Penguasaan kesulitan yang relatif kecil oleh anak-anak dan ramaja penting untuk mengembangkan ketahanan terhadap tantangan selanjutnya (Shonkoff, Boyce, \& McEwen, 2009). Namun, tingkat stres yang terkait dengan kesulitan yang berlebihan, persisten atau tidak terkendali, tanpa perlindungan dukungan orang dewasa yang stabil dapat memberikan efek mengganggu pada fungsi otak (dan beberapa sistem organ) yang dapat menyebabkan penyakit seumur hidup dan masalah perilaku (Shonkoff et al., 2009).

Peran dukungan teman sebaya memberikan dukungan sosial kepada remaja untuk dapat beradaptasi dalam keadaan sedih/ tertekan. Kemampuan adaptasi psikologis seseorang dapat dilihat melalui resiliensi atau resistensi terhadap perubahan keadaan. Ada dua poin utama ketahanan (resiliensi), yaitu kompetensi pribadi dan penerimaan diri dan kehidupan. Kompetensi pribadi adalah kemampuan individu dalam manajemen diri termasuk kebebasan, kemandirian, tekad, tak terkalahkan, mahir, pintar, dan tekun. Penerimaan diri dan kehidupan adalah sikap positif terhadap diri sendiri dan mengakui dan 
menerima banyak aspek diri dan kehidupan, termasuk penyesuaian, keseimbangan, fleksibilitas, dan keseimbangan perspektif kehidupan (Wagnild \& Young, 1993).

Dalam hal ini, hubungan antara strategi manajemen konflik dan kecerdasan emosional perlu diselidiki dalam konteks keperawatan. Tujuan dari penelitian ini adalah untuk menyelidiki peran kecerdasan emosional dalam strategi manajemen konflik perawat. Konflik yang terkontrol akan menghasilkan integrasi. Sebaliknya, integrasi yang tidak sempurna dapat menciptakan konflik. Jawaban untuk pertanyaan berikut ini dicari dalam penelitian untuk tujuan ini: "Apakah ada hubungan yang signifikan antara peran dukungan sosial teman sebaya dan ketahanan psikologis remaja yang mengalami konflik

\section{METODE PENELITIAN}

1. Rancangan Penelitian

Penelitian ini merupakan penelitian korelasional menggunakan desain crosssectional, untuk menguji hubungan antara peran dukungan sosial teman sebaya dan ketahanan psikologis remaja yang mengalami konflik dan masalah emosional akibat bullying. Penelitian dilaksanakan di Kediri, Indonesia

2. Populasi dan Sampel

Sebanyak 1044 remaja adalah populasi target untuk penelitian. Perhitungan untuk menentukan jumlah peserta untuk penelitian ini didasarkan pada literatur terkini, dan rancangan penelitian (Faul, Erdfelder, Buchner, \& Lang, 2009). Power Analysis digunakan untuk memperkirakan ukuran sampel dilakukan dengan menggunakan perangkat lunak (Faul et al., 2009). Penentuan besar sampel dalam penelitian ini menggunakan A priori power analysis dengan aplikasi free G-power software version 3.1.9.2". Power Analysis memperkirakan bahwa jumlah sampel total (N) 94 siswa diperlukan untuk memenuhi penelitian ini dengan menggunakan tingkat alfa (a) standar yang ditetapkan pada 0,05 untuk uji dua sisi, dengan ukuran efek kecil 0,30 (Cohen, 2001) dan kekuatan standar 0,80 . Sampel dalam penelitian ini diambil dengan simple random sampling sebanyak 94 responden. Kriteria inklusi semua siswa SMPN 3 Kediri yang pernah mengalami bullying 1 tahun yang lalu usia 12-15 tahun (berdasarkan hasil survei kuesioner). Kriteria eksklusi pada penlitian ini adalah remaja yang tidak masuk karena izin, alpha, ataupun sakit.

3. Teknik pengumpulan data dan pengembangan instrumen

Sebelum tahap pengumpulan data, ijin untuk melakukan penelitian diperoleh dari administrasi universitas dan administrasi penelitian di lokasi penelitian ini. Penelitian ini disetujui oleh komite etika penelitian kesehatan dari universitas (ethical approval no.: 690-KEPK). Responden diberikan penjelasan sebelum memulai penelitian, sampai persetujuan lisan mereka diperoleh. Selain itu, ijin tertulis diperoleh dari penulis untuk alat ukur yang digunakan dalam penelitian.

Pengukuran :

1. Formulir informasi pribadi

Instrumen ini dibuat disusun oleh peneliti berupa kuesioner untuk mendapatkan gambaran dan karakteristik responden tentang Faktor Predisposisi Sosiokultural meliputi usia, jenis kelamin, latar belakang budaya, dan pengalaman sosialisasi, riwayat keluarga, dan pengalaman masa lalu.

2. The Perceived Social Support from Family (PSS-Fa) Scale 


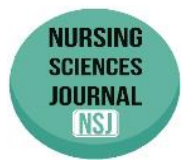

PSS-Fr (Perceived Social Support- Friend) masing-masing terdiri dari 20 item kuesioner. Setiap terdiri dari pernyataan deklaratif dimana individu tersebut menjawab "Ya," "Tidak," atau "Tidak tahu." Untuk setiap item, tanggapan menunjukkan dukungan sosial yang dirasakan dinilai sebagai +1 sehingga skor berkisar dari 0 , menunjukkan tidak ada dukungan sosial teman sebaya yang dirasakan, sampai 20, yang mengindikasikan dukungan sosial teman sebaya yang dirasakan secara maksimal, seperti yang diberikan oleh keluarga atau teman. (Kategori "Tidak Tahu" tidak diberi nilai.)

PSS-Fr lebih dekat kaitannya dengan kompetensi sosial. PSS-Fa tidak terpengaruh oleh keadaan mood positif atau negatif (pernyataan diri), namun hasil PSS-Fr yang rendah dipengauhi oleh keadaan mood yang negatif. Skor pada subyek PSS-Fr yang tinggi menujukkan gejala kecemasan yang rendah dan kemampuan sosial yang baik ,namun jika skor PSS-Fr rendah menunjukkan adanya kecemasan dan membutuhkan dukungan karena berbicara tentang diri mereka melebihi kepada teman dan saudara kdanung (Procidano \& Heller, 1983).

\section{The Resilience Scale (RS)}

The Brief Resilience Scale (BRS) adalah kuesioner yang dibuat untuk mengukur kemampuan individu untuk "bangkit kembali" dari tekanan atau stres, belum digunakan pada populasi klinis, namun dapat memberi beberapa wawasan penting bagi individu mengenai kesehatan terkait stress. Instrumen BRS terdiri dari enam item, tiga item bernada positif dan tiga item berurutan negatif. Keenam kuesioner berhubungan dengan kemampuan individu untuk bangkit kembali dari kesengsaraan. Perkembangan skala ini dikendalikan untuk faktor pelindung seperti dukungan sosial untuk mendapatkan ukuran ketahanan yang handal. The BRS memiliki korelasi yang positif terhadap keyakinan posistif dan koping aktif sehingga dapat digunakan untuk mengukur variabel tersebut (Smith et al., 2008)

Pada pernyataan dalam kuesioner untuk item 1, 3, dan 5 bernada positif, dan item 2, 4, dan 6 diberi bernada negatif. Kuesioner BRS dinilai dengan item pengkodean terbalik 2, 4, dan 6 dan menemukan mean dari enam item. Petunjuk pengisian untuk mendapatkan datanya sebagai berikut ; "Tolong tunjukkan sejauh mana Anda setuju dengan setiap pernyataan berikut dengan menggunakan skala berikut: $1=$ sangat setuju, 2 = tidak setuju, $3=$ netral, $4=$ setuju, 5 = sangat setuju." Skor rata-rata digunakan untuk menciptakan skor ketahanan dengan skor yang lebih tinggi yang mencerminkan tingkat ketahanan yang lebih tinggi (Smith et al., 2008). Rentang skor yang mungkin pada BRS adalah dari 1 (ketahanan rendah) hingga 5 (ketahanan tinggi). Skor di bawah 3,00 dianggap rendah, 3.01-4.29 normal, dan skor di atas 4,30 dipertimbangkan tinggi dalam ketahanan (Smith et al., 2008)

Pengumpulan Data :

Peneliti mengurus perizinan penelitian diprogram Studi Magister Keperawatan Universitas Airlangga, Dinas Pendidikan Kota Kediri, dan SMPN 3 Kediri. Surat ijin dikirim ke lokasi penelitian untuk tujuan perekrutan. Ketika ijin diperoleh, peneliti mengunjungi lokasi penelitian untuk mendistribusikan kuesioner. Pengumpulan data memakan waktu sekitar 2 bulan. Peneliti meminta agar kuesioner diisi oleh peserta. Selama periode pengumpulan data, persetujuan tertulis dan kuesioner yang dijawab diperlakukan secara terpisah sehingga tanggapan para peserta tidak akan diekspos.

4. Teknik Analisa Data 
Data yang dikumpulkan dianalisis menggunakan SPSS 22. Dalam analisis data, distribusi frekuensi, distribusi persentase, mean dihitung; dan analisis korelasi Pearson $(p<.05)$ digunakan untuk statistik signifikansi

\section{HASIL DAN PEMBAHASAN}

1. Karakteristik Responden

Usia rata-rata remaja dalam penelitian ini adalah 14 tahun.

Tabel 1. Karakteristik Responden

\begin{tabular}{lcc}
\hline \multicolumn{1}{c}{ Karakteristik } & Kategori & $\mathrm{n}(\%)$ \\
\hline Jenis kelamin & Laki-laki & $39(41,48 \%)$ \\
Umur & Perempuan & $61(58,62 \%)$ \\
& 12 & $3(3,1 \%)$ \\
& 13 & $31(32,9 \%)$ \\
Pendidikan & 14 & $57(60,6 \%)$ \\
\hline
\end{tabular}

2. Tingkat Dukungan Sosial Teman Sebaya dan Ketahanan Psikologis

Skor rata-rata responden untuk dukungan sosial teman sebaya berdasarkan dari PSS-Fr adalah 11,33 (kisaran 0-20). Nilai rata-rata yang ketahanan/ resiliensi remaja adalah 19,462 (kisaran 0-30).

3. Hubungan antara Dukungan Sosial Teman Sebaya dan Ketahanan Psikologis

Analisis korelasi digunakan untuk menggambarkan kekuatan hubungan antara dukungan sosial teman Sebaya dan ketahanan Psikologis remaja yang mengalami konflik dan masalah emosional akibat bullying. Hasilnya menunjukkan bahwa ada korelasi positif yang signifikan antara dukungan sosial teman sebaya dengan ketahanan psikologis remaja $(p<0.05)$.

Hasil penelitian menjelaskan bahwa dukungan teman memiliki pengaruh terhadap ketahanan psikologis remaja yang mengalami konflik. Dukungan teman berbanding lurus dengan ketahanan psikologis remaja, maksudnya adalah bila dukungan teman pada remaja tinggi maka ketahanan psikologis juga ikut tinggi, dan sebaliknya. Apabila dukungan teman rendah maka erat hubungannya dengan ketahanan psikologis yang rendah.

Bullying menyebabkan risiko psikososial dan penyesuaian akademik yang serius pada korban dan pelakunya (Solberg, Olweus, \& Endresen, 2007). Gangguan kesehatan mental telah terbukti memiliki efek merugikan yang signifikan pada kesejahteraan, fungsi dan perkembangan pada masa remaja, dan dikaitkan dengan penurunan prestasi akademik, pengangguran, fungsi sosial yang buruk, dan penyalahgunaan zat. Efek negatif ini bisa berlanjut jauh melampaui masa remaja, menciptakan siklus disfungsi dan kerugian yang terus berlanjut (Yin et al., 2017).

Dampak dibidang pendidikan bagi korban bullying dan kekerasan sangat signifikan. Bullying yang dilakukan oleh guru atau teman sebaya dapat membuat anak-anak dan remaja yang dibullying merasa takut untuk pergi ke sekolah dan mengganggu kemampuan mereka untuk berkonsentrasi di kelas atau berpartisipasi dalam kegiatan sekolah (UNESCO, 2017). Mereka mungkin sering kehilangan kelas, menghindari kegiatan sekolah, dan putus sekolah sama sekali. Lingkungan belajar yang tidak aman menciptakan iklim ketakutan dan 
ketidakamanan serta menimbulkan persepsi bahwa guru tidak memiliki kendali atau peduli terhadap kesejahteraan siswa. Hal ini mengurangi kualitas pendidikan bagi semua siswa (UNESCO, 2017).

Pada tingkat lingkungan mikro, dukungan sosial, termasuk hubungan dengan keluarga dan teman sebaya, berkorelasi dengan ketahanan. Dukungan sosial bisa berasal dari teman sebaya, guru yang suportif, dan orang dewasa lainnya serta keluarga dekat (Luthar, Cicchetti, and Becker, 2000).

Beberapa penelitian mengemukakan bahwa dukungan dari teman sekolah dan lingkungan sangat berpengaruh terhadap ketahanan psikologis dan kesehatan mental individu yang mengalami konflik seperti bullying (Lerner et al., 2013; Ungar, Russell dan Connelly, 2014; Yin et al., 2017). Protektif faktor yang mempengaruhi ketahanan psikologis anak yang mengalami konflik dan menjadi korban bullying usia 13-14 di Australia adalah dukungan teman. Dukungan teman bias memberi perlindungan siswa konflik korban bullying dari dampak psikologis yang negatif seperti depresi dan stres. Vassallo et al., (2014). Dukungan teman sebaya di lingkungan sekolah, relatif lebih mudah didapatkan dan efektif dibandingkan dengan dukungan keluarga karena banyak waktu yang dihabiskan remaja di sekolah (Natvig, Albrektsen dan Qvarnstrøm, 2001). Sebagian besar remaja yang diganggu dan yang tidak mendapat dukungan sosial teman sebaya di sekolah, dapat memberikan dampak terganggunya kemampuan akademik dan efek psikologis yang buruk (Espelage dan Holt, 2001). Bagi sebagian korban, konflik pada masa remaja merupakan masalah sosial yang signifikan bila tidak segera diselesaikan dan menjadi persisten dari waktu ke waktu (Calvete, Fernández-González, González-Cabrera, \& Gámez-Guadix, 2017).

Menurut teori ketahanan, Paparan resiko negatif pada remaja dapat diturunkan resikonya dengan cara meningkatknan faktor pelindung seperti faktor promotif (Fergus dan Zimmerman, 2005). Dukungan sosial seperti dukungan emosi maupun dukungan material (dukungan keluarga dan dukungan teman sebaya) dapat membantu remaja mengatasi efek negatif dari stresor baik itu stressor fisik ataupun psikologis (Atri dan Sharma, 2006). Dukungan sosial terbukti sebagai faktor pelindung yang baik dan utama terhadap masalah internal remaja yang mengalami konflik bullying. Dengan demikian untuk mengurangi resiko negatif yang ditimbulkan dapat memperkuat faktor pelindung (Rutter, 1987).

Dukungan sosial teman memberikan kesempatan seseorang untuk merasa mendapatkan kekuatan baru dari eksternal, dihargai, diperhatikan, membantu pemecahan masalah, sehingga dapat meringankan efek negatif dari kesulitan.dan meningkatkan ketahanan remaja

\section{KESIMPULAN DAN SARAN}

Studi ini mengidentifikasi korelasi antara dukungan sosial teman sebaya dan ketahanan psikologis remaja yang mengalami konflik dan masalah emosional akibat bullying. Hal ini menunjukkan bahwa dukungan sosial teman sebaya memiliki dampak positif dalam meningkatkan ketahanan pada psikologis remaja. Disarankan bahwa studi lebih lanjut dapat menyelidiki faktor lain yang mempengaruhi masalah kesehatn emosional pada remaja. Faktor baru yang berbeda memberikan pandangan baru bagi perawat dalam memberikan asuhan keperawatan 


\section{UCAPAN TERIMA KASIH}

Terimakasih kepada anggota peneliti, instansi dan Lembaga, serta seluruh pihak yang telah membantu penyelesaian laporan penelitian ini

\section{DAFTAR PUSTAKA}

Adams, S. (2015). Psychiatric Mental Health Nursing: "A Seat at the Table." Journal of the American Psychiatric Nurses Association, 21(1), 34-37. https://doi.org/10.1177/948390314567945

Atri, A., \& Sharma, M. (2006). Designing a mental health education program for South Asian international students in United States. Californian Journal of Health Promotion, 4(3), 135-145. Retrieved from http://search.ebscohost.com/login.aspx?direct=true\&db=rzh\&AN=1051721 40\&amp\%5Cnlang=ja\&site=ehost-live

Bhatla, N., Achyut, P., Khan, N., \& Walia, S. (2014). Are Schools Safe and Gender Equal Spaces? Findings from a baseline study of school related gender-based violence in five countries in Asia. https://doi.org/10.1017/CBO978194415324.004

Bonanno, G. A. (2004). Loss, Trauma, and Human Resilience: Have We Underestimated the Human Capacity to Thrive after Extremely Aversive Events? American Psychologist, 59(1), 20-28. https://doi.org/10.1037/0003-066X.59.1.20

Calvete, E., Fernández-González, L., González-Cabrera, J. M., \& Gámez-Guadix, M. (2017). Continued Bullying Victimization in Adolescents: Maladaptive Schemas as a Mediational Mechanism. Journal of Youth and Adolescence, pp. 1-11. Springer US. https://doi.org/10.1007/s10964-017-0677-5

Cohen, A. (2001). Nations for mental health, the effec- tiveness of mental health services in commu- nity care: the view from the developing world. WHO, Geneva.

Espelage, D. L., \& Holt, M. K. (2001). Conversations with Middle School Students About Bullying and Victimization. Journal of Emotional Abuse, 2(2-3), 4962. https://doi.org/10.1300/J135v02n02

Faul, F., Erdfelder, E., Buchner, A., \& Lang, A.-G. (2009). Statistical power analyses using $\mathrm{G} *$ Power 3.1: Tests for correlation and regression analyses. Behavior Research Methods, 41(4), 1149-1160. https://doi.org/10.3758/BRM.41.4.1149

Fergus, S., \& Zimmerman, M. A. (2005). ADOLESCENT RESILIENCE: A Framework for Understanding Healthy Development in the Face of Risk. Annual Review of Public Health, 26(1), 399-419. https://doi.org/10.1146/annurev.publhealth.26.021304.144357

Kemenkes RI. (2016). Data dan Informasi Profil Kesehatan Indonesia. Yoeyoen Aryantin Indrayani S.Ds; B. B. Sigit; Sinin. Retrieved from http://www.depkes.go.id/resources/download/pusdatin/lain-lain/Data dan Informasi Kesehatan Profil Kesehatan Indonesia 2016 - smaller size web.pdf

Lerner, R. M., Agans, J. P., Arbeit, M. R., Chase, P. A., Weiner, M. B., Schmid, K. L., \& Warren, A. E. A. (2013). Resilience and Positive Youth Development: A Relational Developmental Systems Model. Handbook of Resilience in Children, 1-527. https://doi.org/10.1016/j.jpeds.2017.06.030

Lessne, D., \& Yanez, C. (2016). Student reports of bullying and cyber-bullying: Results from the 2015 school crime supplement to the national crime 
victimization survey.

Luthar, S. S., Cicchetti, D., \& Becker, B. (2000). The construct of resilience: A critical evaluation and guidelines for future work. Child Development. https://doi.org/10.1111/1467-8624.00164

Mellor, A. (1995). Which Way Now? A Progress Report on Action against Bullying in Scottish Schools. Research Report Series, (June), 89.

Murshid, N. S. (2017). Bullying victimization and mental health outcomes of adolescents in Myanmar, Pakistan, and Sri Lanka. Children and Youth Services Review, 76, 163-169. https://doi.org/10.1016/j.childyouth.2017.03.003

Natvig, G. K., Albrektsen, G., \& Qvarnstrøm, U. (2001). School-related stress experience as a risk factor for bullying behavior. Journal of Youth and Adolescence, 30(5), 561-575. https://doi.org/10.1023/A:1010448604838

Nugroho, A. (2017a, July). Gampang Emosi karena Paparan Media Sosial. Radar Kediri. Nganjuk. Retrieved from https://www.jawapos.com/radarkediri/read/2017/07/24/3307/setelahvideo-bullying-abk-smpn-4-nganjuk-viral

Nugroho, A. (2017b, September). Setelah Video Bullying ABK SMPN 4 Nganjuk Viral. Radar Kediri. Kediri. Retrieved from https://www.jawapos.com/radarkediri/read/2017/09/13/13355/gampangemosi-karena-paparan-media-sosial

Peltzer, K., \& Pengpid, S. (2017). Suicidal ideation and associated factors among students aged 13???15 years in Association of Southeast Asian Nations (ASEAN) member states, 2007???2013. International Journal of Psychiatry in Clinical Practice, pp. 1-8. Informa UK Limited, trading as Taylor 8 Francis Group. https://doi.org/10.1080/13651501.2017.1301486

Pinheiro, P. S. P. S. (2006). World Report on Violence Against Children. Geneva: UN. Retrieved from https://www.unicef.org/violencestudy/I. World Report on Violence against Children.pdf

Procidano, M. E., \& Heller, K. (1983). Measures of Perceived Social Support From Friends and From Family: Three Validation Studies 1, 11(1), 1-24.

Rasalingam, A., Clench-Aas, J., \& Raanaas, R. K. (2016). Peer Victimization and Related Mental Health Problems in Early Adolescence: The Mediating Role of Parental and Peer Support. The Journal of Early Adolescence, 1-21. https://doi.org/10.1177/0272431616653474

Rhee, S., Lee, S., \& Jung, S. (2017). Ethnic differences in bullying victimization and psychological distress: A test of an ecological model *. Journal of Adolescence, 1-6. https://doi.org/10.1016/j.adolescence.2017.07.013

Rini, C. L. (2014). Indonesia Masuk Kategori Darurat Bullying di Sekolah. Retrieved November 18, 2017, from http://www.beritasatu.com/gayahidup/219515-indonesia-masuk-kategori-darurat-Bullying-di-sekolah.html

Rutter, M. (1987). PSYCHOSOCIAL RESILIENCE AND PROTECTIVE MECHANISMS. American Journal of Orthopsychiatry, 57(3), 316-331. https://doi.org/10.1111/j.1939-0025.1987.tb03541.x

Saubani, A., \& Sopia, S. (2017). Komnas HAM Sebut Bullying Sebagai Fenomena Gunung Es - Republika Online. Retrieved from http://nasional.republika.co.id/berita/nasional/umum/17/07/18/ot9mylkomnas-ham-sebut-bullying-sebagai-fenomena-gunung-es

Setyawan, D. (2014). KPAI: Kasus Bullying dan Pendidikan Karakter, Komisi Perlindungan Anak Indonesia (KPAI). Retrieved from 
http://www.kpai.go.id/berita/kpai-kasus-bullying-dan-pendidikan-karakter/

Shonkoff, J. P., Boyce, W. T., \& McEwen, B. S. (2009). Neuroscience, molecular biology, and the childhood roots of health disparities: Building a new framework for health promotion and disease prevention. JAMA - Journal of the American Medical Association, 301(21), 2252-2259. https://doi.org/10.1001/jama.2009.754

Smith, B. W., Dalen, J., Wiggins, K., Tooley, E., Christopher, P., \& Bernard, J. (2008). The brief resilience scale: Assessing the ability to bounce back. International Journal of Behavioral Medicine, 15(3), 194-200. https://doi.org/10.1080/9405500802222972

Solberg, M. E., Olweus, D., \& Endresen, I. M. (2007). Bullies and victims at school: Are they the same pupils? British Journal of Educational Psychology, 772), 441-464. https://doi.org/10.1348/000709906X105689

Sukarelawati, E. (2017). Polisi Selidiki Kasus _Bullying_di SMP Tulungagung ANTARA News Jawa Timur. Retrieved November 14, 2017, from http://www.antarajatim.com/lihat/berita/142634/polisi-selidiki-kasusbullying-di-smp-tulungagung

Tanrikulu, I., \& Campbell, M. (2015). Children and Youth Services Review Correlates of traditional bullying and cyberbullying perpetration among Australian students. Children and Youth Services Review, 55, 138-146. https://doi.org/10.1016/j.childyouth.2015.06.001

Undheim, A. M., Wallander, J., \& Sund, A. M. (2016). Coping Strategies and Associations With Depression Among 12- to 15-Year-Old Norwegian Adolescents Involved in Bullying. The Journal of Nervous and Mental Disease, 204(4), 274-279. https://doi.org/10.1097/NMD.0000000000000474

UNESCO. (2011). GLOBAL EDUCATION DIGEST 2011 Comparing Education Statistics Across the World. Canada: UNESCO Institute for Statistics.

UNESCO. (2017). School Violence and Bullying: Global Status Report. Paris: United Nations Educational, Scientific and Cultural Organization.

Ungar, M., Russell, P., \& Connelly, G. (2014). School-Based Interventions to Enhance the Resilience of Students. Journal of Educational and Developmental Psychology, 4(1), 66-83. https://doi.org/10.5539/jedp.v4n1p66

Vassallo, S., Edwards, B., Renda, J., \& Olsson, C. A. (2014). Bullying in Early Adolescence and Antisocial Behavior and Depression Six Years Later: What Are the Protective Factors? Journal of School Violence, 13(1), 100-124. https://doi.org/10.1080/15388220.2013.840643

Wagnild, G. M., \& Young, H. M. (1993). Development and Psychometric Evaluation of the Resilience Scale. Journal of Nursing Measurenment, 1(2). Retrieved from https://sapibg.org/download/1054wagnild_1993_resilience_scale_2.pdf

Yin, X. Q., Wang, L. H., Zhang, G. D., Liang, X. B., Li, J., Zimmerman, M. A., \& Wang, J. L. (2017). The promotive effects of peer support and active coping on the relationship between bullying victimization and depression among chinese boarding students. Psychiatry Research, 256(1), 59-65. https://doi.org/10.1016/j.psychres.2017.06.037

Zauszniewski, J. A., \& Bekhet, A. K. (2012). Screening measure for early detection of depressive symptoms: The depressive cognition scale. Western Journal of Nursing Research, 34(2), 230-244. 
https://doi.org/10.1177/0193945910396731

Zhou, Z. K., Liu, Q. Q., Niu, G. F., Sun, X. J., \& Fan, C. Y. (2017). Bullying victimization and depression in Chinese children: A moderated mediation model of resilience and mindfulness. Personality and Individual Differences, 104, 137-142. https://doi.org/10.1016/j.paid.2016.07.040 